\title{
PRZED DZIEŁEM SZTUKI. WSPOMNIENIA ZE STUDIÓW
}

Dla dawnego studenta historii sztuki Uniwersytetu Poznańskiego, a później pracownika Katedry Historii Sztuki tej uczelni, stulecie akademickiego nauczania naszej dyscypliny w stolicy Wielkopolski jest naturalną okazją do refleksji nad środowiskiem naukowym, które go ukształtowało. Ma on przy tym przed sobą do wyboru dwie drogi, którymi podążać może, temat ten podejmując. Może próbować opisać to środowisko z punktu widzenia historii nauki i dziejów nauczania uniwersyteckiego, więc - starając się zachować bezstronność - poddać systematycznej analizie osiągnięcia badawcze pracowników ówczesnej Katedry i określić stosowane przez nich metody. Ale może też podążyć inną drogą. Może spojrzeć na swe studia uniwersyteckie oraz na ukształtowany przez nie kierunek pracy intelektualnej z perspektywy własnego życia, więc ująć temat w formie wspomnień osobistych, wiedząc oczywiście, że będą one subiektywne i cząstkowe. Wybieram tutaj to drugie.

Na wykłady z historii sztuki zacząłem chodzić zaraz po złożeniu egzaminu maturalnego w dniu 17 maja 1949, na kilka miesięcy przed immatrykulacją. Przed końcem roku akademickiego zdążyłem jeszcze kilku z nich wysłuchać. Były to wykłady księdza profesora Szczęsnego Dettloffa o malarstwie weneckim XV wieku. Odbywały się w sali wykładowej Katedry Historii Sztuki, w jej ówczesnej siedzibie na trzecim piętrze Collegium Maius. Pamiętam, że właściwie nic z tego albo prawie nic nie rozumiałem. Kiedy później, na studiach, poznawałem język naszej nauki, kiedy uczyłem się analizy dzieła sztuki, a może przede wszystkim - kiedy stopniowo wkraczałem na trudny grunt oceny miejsca pojedynczego dzieła w procesie artystycznym epoki, zrozumiałem przyczyny tego analfabetyzmu. Studia uświadomiły mi, że percepcja dzieła sztuki zajmuje wśród czynności poznawczych człowieka miejsce odosobnione i że ani szkoła średnia ani dostępna społeczeństwu edukacja powszechna nie były i chyba nadal nie są w stanie młodego umysłu do tego zadania przygotować. Spotkaniu człowieka ze sztuką towarzyszy bowiem poruszenie we- 
wnętrzne, towarzyszą doznania, które powstają poza naturalnym dążeniem umysłu do klasyfikacji gatunkowej oglądanego przedmiotu i do ustalenia jego miejsca w rekonstruowanej przez nas przeszłości. Ale są to doznania, które jednocześnie $\mathrm{w}$ tajemniczy sposób $\mathrm{z}$ intelektualnym procesem szukania w świecie sztuki podobieństw i ich przyczyn się splatają i nań wpływają. To było odkrywanie historii sztuki jako nauki aksjologicznej.

Wykształcenie, jakie wtedy na Uniwersytecie Poznańskim otrzymywaliśmy, ten aspekt naszej dyscypliny z całą wyrazistością ujawniało. Ksiądz Dettloff, który był przez większą część czasu moich studiów kierownikiem Katedry Historii Sztuki (do marca 1953), jedynym w niej wówczas nauczycielem $z$ tytułem profesora i który był dla nas największym autorytetem akademickim - był wybitnym analitykiem formy. Myślę, że dar ten - zapewne wrodzony w znacznym stopniu rozwinął w czasie dwuletnich studiów w Monachium, gdzie słuchał wykładów Heinricha Wölfflina. A to przecież w analizie formy i w wyrażających ją słowach przejawia się wartościowanie utworu artystycznego - zabieg intelektualny, który pozwala umieścić dzieło w określonym miejscu wielkiej skali przedmiotów, którym przyznajemy tajemniczą siłę budzenia w nas zachwytu, wręcz zapominania o otaczającej nas rzeczywistości. Kiedy byłem na I roku studiów, ks. Dettloff prowadził wykład pt. „Sztuka włoska XVI wieku" w wymiarze czterech godzin tygodniowo. Część tego czasu przeznaczał na ćwiczenia w galerii malarstwa włoskiego ówczesnego Muzeum Wielkopolskiego, dzisiaj Narodowego. Każdy ze słuchaczy miał obowiązek opracowania jednego z obrazów tej kolekcji i przedstawienia w krótkim referacie swoich wyników. Było wiele osób, które chodziły na te zajęcia. Obok nas, studentów I roku, którzy uczyliśmy się już według nowego, ustalonego przez komunistyczne władze dwustopniowego programu studiów, w zajęciach prowadzonych przez ks. Dettloffa brali udział także słuchacze wcześniejszych roczników. Ci studiowali według programu przedwojennego, odmiennego od naszego - przeciążonego licznymi wykładami o encyklopedycznym charakterze. W dawnym programie dominowały zajęcia, które słuchacza od razu stawiały przed wielkimi zjawiskami i postaciami w dziejach sztuki i które w rezultacie szyblko zapoznawały go z głównymi metodami pracy dyscypliny. Ksiądz Dettloff nie inaczej też rozumiał rolę swoich ćwiczeń prowadzonych w galerii malarstwa włoskiego poznańskiego muzeum. Wiemy, że znajdują się w niej obrazy, które mogą być dobrym punktem wyjścia do studiów nad sztuką nowożytną.

Mnie przypadło opracowanie płótna Riva degli Schiavoni, którego autorem jest Luca Carlevarijs. Pamiętam, że natrudziłem się wtedy bardzo, by obraz opisać i zgromadzić jakieś o nim wiadomości, ale dopiero kiedy po moim nieporadnym wystąpieniu głos zabrał ks. Dettloff, zrozumiałem, czym może być analiza dzieła sztuki i czym jego interpretacja. Nasz profesor zaczął od 
opisu przedstawionego przez artystę miejsca w Wenecji i zaraz mistrzowsko związał wiadomości o przedmiocie wyobrażenia z rozbiorem kompozycji i środków malarskich, którymi malarz w obrazie się posłużył. Od tego wychodząc, poszedł w kilku kierunkach. Najpierw opowiedział nam o artyście i o tematach jego dzieł. Potem o środowiskach artystycznych i twórcach, od których był on zależny. Wreszcie o gatunku, w którym głównie się wypowiadał - o pejzażu miejskim i o jego weneckiej formule. Słuchając tego wywodu, odkrywaliśmy, że ks. Dettloff prowadzi nas od oglądu obrazu do wiedzy, którą zapisała ludzka pamięć, a wiedza ta jest czymś zupełnie innym niż to, co zmysł wzroku pozwala nam w obrazie odczytać: jakiś mały fragment świata zewnętrznego. I choć nic właściwie albo prawie nic wtedy o Wenecji i o jej malarstwie, o weducie czy o perspektywie nie wiedzieliśmy, odkrywaliśmy, że tylko wnikliwe w dzieło sztuki wejrzenie może to, co zgromadził intelekt, na pamięć przywołać i z wyobrażeniem związać. Była to wielka lekcja lektury dzieła sztuki. Zaczynała się od analizy formy, a ks. Dettloff wyczucie formy i jej miejsca w tym, co porównywalne, miał bezbłędne.

Jeszcze bliżej danym było mi ten talent ks. Dettloffa poznać przy końcu tego samego roku akademickiego, w maju 1950. Wyjechaliśmy wtedy z naszym profesorem - wszystkie roczniki poznańskiej historii sztuki - na dziesięć dni do Krakowa. Profesor Jerzy Szablowski pozwolił nam w czasie tego pobytu obejrzeć rzeźby ołtarza mariackiego Wita Stwosza. Leżały one wtedy w wielkiej sali, w południowo-zachodnim skrzydle budynku administracyjnego Państwowych Zbiorów Sztuki na Wawelu. Zgromadzono je tam i zatrzymano po ich odzyskaniu z Niemiec, ponieważ władze komunistyczne nie pozwalały wówczas na ich powrót do kościoła Mariackiego. Zwrócono je właścicielowi później, po zmianach politycznych, jakie zaszły po październiku 1956. Szczęśliwie, kiedy trwał ten areszt, zespół specjalistów pod kierunkiem profesora Mariana Słoneckiego mógł prowadzić przy dziele Stwosza prace konserwatorskie. Nie tylko uchroniło to rzeźby przed zniszczeniem, jakie im już groziło ze strony owadów żerujących w drewnie, lecz także doprowadziło do odkrycia i do utrwalenia ich pierwotnej polichromii. Oglądanie figur i reliefów wyjętych ze struktury retabulum i rozstawionych bez wzajemnego związku w różnych miejscach wielkiego pomieszczenia nie mogło oczywiście sprzyjać poprawnej percepcji Stwoszowego dzieła. Pojedyncze rzeźby były bowiem przez artystę pomyślane jako integralne części większych kompozycji, np. środkowej sceny nastawy czy kwater na jej skrzydłach, i tylko w obrębie tych kompozycji zrozumiała stawała się forma każdej figury. Ale wychodząc od analizy formy tych pojedynczych składników retabulum ołtarzowego i pokazując nam przy tym jego przedwojenne fotografie, potrafił ks. Dettloff wywołać w naszej wyobraźni obraz dzieła w całej jego złożonej relacji między 
szczegółem i całością. Jednocześnie wspaniale ukazywał, w jaki sposób wielki rzeźbiarz wykształcony w Sztrasburgu w XV wieku buduje figurę ludzką.

Uczył nas ks. Dettloff także wnikania w formę w sztukach nieprzedstawiających. Do dzisiaj nie mogę zapomnieć dwóch jego wystąpień. Jedno z nich miało miejsce w kościele pojezuickim w Poznaniu, gdzie otwierał nam oczy na to, jak w baroku ścierają się ze sobą - ale i łączą - dwa kierunki ciągów przestrzeni wnętrza w architekturze: jeden wzdłużny i liczne poprzeczne. Drugie miało miejsce w Sierakowie, w kościele pobernardyńskim. Na tym przykładzie pokazywał nam ks. Dettloff, jak w pierwszej połowie XVII wieku formy klasycznego Renesansu - przekształcone w dekorację, zwielokrotnione i zagęszczone - biorą rozbrat ze swoją antyczną genezą i tracąc swoją strukturalną funkcję, stają się swobodnym elementem ruchliwej artykulacji ściany, sklepienia czy czaszy kopuły.

Tę samą wrażliwość na formę odkrywał poznański student historii sztuki tamtych lat u dwóch innych swoich profesorów - obu uczniów ks. Dettloffa Gwidona Chmarzyńskiego i Zdzisława Kępińskiego.

Gwido Chmarzyński - jak wiemy - pozostawił po sobie niewiele publikacji. Ja zapamiętałem go przede wszystkim jako wybitnego dydaktyka, który mówił o sztuce z pasją właściwą krytykowi i koneserowi. Jego emocjonalne wręcz zaangażowanie w przedmiot wykładu ujawniało się najsilniej, kiedy mówił o tym, co znał najlepiej - o architekturze gotyku, a zwłaszcza wtedy, gdy stawał z nami przed kościołem gotyckim lub w jego wnętrzu. Chmarzyński z wszystkich ówczesnych pracowników katedry bodaj najchętniej i najczęściej brał udział w wyjazdach w teren. Poznawaliśmy z nim wtedy obok Wielkopolski głównie Śląsk, Pomorze i Ziemię Chełmińską. Ta ostatnia była mu najbliższa i to jej kościoły, np. dawna katedra w Chełmży czy kościół św. Jana w Toruniu, były miejscem, gdzie chyba najwyraźniej odsłaniał swoje spojrzenie na architekturę gotycką. Najpierw była to zawsze sumienna inwentaryzacja tego, co zapewnia budowli stabilność, i tego, co daje wyraz ukrytym w niej siłom i napięciom. Ale potem potrafił Gwido Chmarzyński swym opisem zamienić ten stabilny świat struktury i jej zewnętrznych elementów w fascynujący obraz żyjących form. Moja pamięć zapisała Gwidona Chmarzyńskiego wśród tych, co najtrafniej mówili o architekturze gotyckiej.

$\mathrm{Na}$ innym miejscu, kilka lat temu, pisałem już o tym, że nasze - studentów - pierwsze spotkanie ze Zdzisławem Kępińskim kazało nam postawić sobie pytanie o kształt historii sztuki, z jaką będziemy mieli do czynienia, odkąd ten nowy wykładowca pojawił się w poznańskiej katedrze z początkiem roku akademickiego 1952/1953. Wykład bowiem, którym zapoczątkował on swoją działalność dydaktyczną i który należał do obowiązkowych zajęć na na- 
szym - wtedy czwartym - roku studiów, nosił tytuł „Rozwój nurtu realistycznego w sztuce”. W tamtych latach, w czasie szalejącego stalinizmu, słowa "realizm” i „realistyczny” miały tylko jedno znaczenie. Za ich pomocą partia komunistyczna i jej ideologowie definiowali zgodność sztuki z tym, co uważali za postęp ludzkości, co było w ich oczach politycznie słuszne, przy czym terminy te mogły kwalifikować zjawiska artystyczne zarówno współczesne, jak i te, które zaszły w przeszłości. Pierwsze wykłady Zdzisława Kępińskiego nie rozwiały naszych obaw. Przeciwnie. Nowy profesor zapowiedział, że będzie mówił o malarstwie Trecenta we Florencji, ale przedmiotem pierwszych godzin był opis sytuacji społecznej, gospodarczej i politycznej w stolicy Toskanii, przy czym znaczną uwagę poświęcił wykładowca wielkim rodzinom florenckim, ich majątkom i prowadzonym przez nie operacjom finansowym. Kiedy jednak zaczął mówić o malarstwie Florencji, cały ten świat wobec twórczości artystycznej zewnętrzny nagle zniknął z przedmiotu wykładu. Słuchaliśmy odtąd o sztuce, a to, co słyszeliśmy, było mistrzowską analizą formy wyrażoną wyrafinowanym językiem. Dzieje zamówień i działania fundatorów, owszem, miały swoje miejsce w tym wywodzie, ale to dzieła artystów tworzyły wątek narracji. Wykład Zdzisława Kępińskiego o malarstwie włoskim okresu między „Czarną Śmiercią" a Masacciem - jestem tego pewien - odegrał w mojej formacji historyka sztuki dużą rolę. Uświadomił mi znaczenie ewolucji form przedstawiających w tym przełomowym dla sztuki europejskiej miejscu i czasie. Więcej, zachęcił do stawiania pytań o zagadnienie ewolucji form w ogóle. Jakiś czas później dowiedziałem się od Eugeniusza Krygiera o okolicznościach, w jakich Zdzisław Kępiński zetknął się po raz pierwszy z malarstwem Florencji i jak to spotkanie przeżył. Obydwaj otrzymali stypendium państwowe na podróż do Włoch w roku 1938 i razem się tam udali. Eugeniusz Krygier opowiadał mi, że jego towarzysz - zafascynowany stolicą Toskanii - pozostał w niej sam wiele dni dłużej, niż początkowo przewidywał ich wspólny plan zwiedzania, i że długie godziny spędzał na oglądaniu malarstwa we florenckich muzeach, kościołach i pałacach. Później jeszcze wielokrotnie miałem okazję podziwiać wyczucie formy w sztuce, jakim natura obdarzyła Zdzisława Kępińskiego.

Zatrzymałem się dłużej nad wykształceniem, jakie otrzymywaliśmy wtedy w poznańskiej katedrze historii sztuki, ponieważ wydaje mi się koniecznym określić bagaż intelektualny, z jakim wyruszaliśmy w świat po studiach w Poznaniu. Wyrażenia „wyruszać w świat” używam celowo. Oddaje ono imperatyw samodzielnego myślenia w warunkach, kiedy już sami, bez niczyjej pomocy, mierzymy się z zadaniami poznawczymi, jakie stawia przed nami nasza własna praca. Opisuje ono także częstą w naszym życiu zawodowym sytuację, która powstaje, kiedy przenosimy się do innego środowiska i tam 
spotykamy się z uprawianiem naszej dyscypliny odmiennym od tego, którego nas uczono. Gdybym miał najkrócej ten bagaż określić, przywołałbym znowu - bo kiedyś już to uczyniłem - słowa Willibalda Sauerländera, którymi opisał on historię sztuki pierwszych trzydziestu lat XX wieku jako „auf Form oder Gestalt konzentrierte”. Miał na myśli historię sztuki w Niemczech, ale na pewno można to sformułowanie odnieść także do sytuacji w innych krajach, w tym w Polsce. Wiemy, w jak bliskim związku z niemieckojęzycznym obszarem historia sztuki u nas powstawała, a jej nauczanie w Poznaniu w czasie moich studiów było kontynuacją nauczania przedwojennego. Z jednym bodaj wyjątkiem wszyscy moi uniwersyteccy nauczyciele swoje wykształcenie otrzymali przed wojną.

Wspominając tamten czas nauki, jednego tematu nie mogę pominąć. Te przedmioty, które partia komunistyczna wprowadziła w latach 1948-1949 do programów uniwersyteckich w celu indoktrynacji przyszłej inteligencji, „materializm dialektyczny i historyczny", "historia ruchu robotniczego", „zagadnienia Polski współczesnej”, „podstawy marksizmu-leninizmu”, „ekonomia polityczna" (podaję tutaj tytuły zajęć zapisane w moim indeksie w rubrykach kolejnych lat studiów), otóż te przedmioty w naszym rozwoju umysłowym nie odegrały żadnej roli. Nie widzieliśmy najmniejszego ich związku z właściwym przedmiotem naszych studiów. Gorzej. Zestawione z wagą zagadnień poznawczych, jakie rodziły w nas prowadzone przez doskonale wykształconych profesorów wykłady z historii sztuki, historii, archeologii, etnologii czy logiki, odsłaniały całą swoją pustkę intelektualną i to, czym naprawdę były: żałosnym instrumentem propagandy politycznej.

Październik 1956 roku przyniósł zmiany w życiu Polaków. Wiemy dobrze, że jeżeli zmiany, jakie wówczas w Polsce nastąpiły, oceniać z perspektywy historii globalnej, to niewiele one znaczyły. Kraj nadal pozostawał częścią składową imperium sowieckiego i nadal panowała w nim dyktatura partii komunistycznej. W niektórych jednak dziedzinach wewnętrznego życia Polski ustąpił - przynajmniej częściowo - paraliż, który przedtem niosła ze sobą stalinowska obsesja budowy społeczeństwa całkowicie podporządkowanego partii i jej ideologii. Sztuki plastyczne i historia sztuki należały do tych dziedzin, które po zmianach październikowych znalazły się poza głównym frontem partyjnej ofensywy ideologicznej. Można wprawdzie bez trudu, dla lat 60. i 70., przytoczyć przykłady bezpośredniej ingerencji najwyższych władz partyjnych albo pojedynczych gorliwych członków partii w twórczość artystyczną niektórych środowisk, w działalność wystawienniczą ważnych instytucji i w projekty wydawnicze z zakresu historii sztuki. Według mojej oceny jednak, działania te nie były ze strony władzy przejawem jakiejś przemyślanej strategii politycznej wobec świata sztuki i nauk o sztuce, lecz doraźną reakcją 
na pojedyncze wydarzenia lub sytuacje, których przywódcy i działacze partyjni nie chcieli tolerować.

Celowo zatrzymałem się tutaj nad zmianami, które nastąpiły w Polsce po październiku 1956. Należę do pokolenia, które od młodości do wieku dojrzałego doznawało ciężaru władzy komunistycznej. Szczeliny, które się w narzuconym przez nią systemie pojawiły - a po październiku 1956 one wystąpiły - miały ogromne znaczenie dla nas, wchodzących wtedy w samodzielność historyków sztuki. Otwierały nieporównanie większą niż wcześniej przestrzeń swobodnych badań nad sztuką i - co najważniejsze - pozwoliły na wyjazdy z dotychczas hermetycznie zamkniętego kraju. Mogliśmy odtąd oglądać sztukę na świecie osobiście, nie za pośrednictwem fotografii. Niektórzy z nas mogli odbyć uzupełniające studia na zagranicznych uniwersytetach, aktywnie uczestniczyć w zjazdach naukowych w innych krajach i nawiązywać bezpośrednie kontakty $z$ wybitnymi przedstawicielami historii sztuki. Chociaż niełatwo do tego dochodziło. Pomijając rzadkie wyjątki, paszport otrzymywał tylko ten, komu instytucja zapraszająca - uniwersytet, muzeum, organizatorzy zjazdu naukowego - zapewniała koszty przejazdu i utrzymania w czasie pobytu za granicą. Ale pamiętać też trzeba, że czasem wydania paszportu odmawiano.

O polityce paszportowej Polski komunistycznej wspominam tutaj po to, by przypomnieć, że polski historyk sztuki, po latach okupacji niemieckiej i stalinizmu, mógł ponownie - mimo rozmaitych trudności - stanąć przed wielkimi dziełami sztuki. Historyk sztuki mojego pokolenia mógł teraz weryfikować swój rodzący się w nim w czasie studiów pogląd na sztukę Europy łacińskiej jako złożony z powiązanych ze sobą członów organizm, jako wytwór jednej cywilizacji. Mógł naocznie przekonać się, że prawdziwie wielkie zmiany w twórczości artystycznej dokonywały się w zachodniej części naszego kontynentu tylko co czas jakiś i tylko w nielicznych środowiskach, które promieniowały potem na zewnątrz. Mając bezpośredni dostęp do wielkich obszarów sztuki europejskiej, mógł - jak nigdy przedtem - ćwiczyć oko i uczyć się rozróżniać dzieła „pierwsze” od ich kontynuacji. Jednocześnie mógł teraz lepiej rozpoznawać miejsce pojedynczego dokonania artystycznego w wielkim gąszczu powiązań i zależności, jaki stanowi świat sztuki.

Jak w praktyce przebiegała ta nauka? Jak zaznaczyłem na wstępie, będę tutaj pisał o własnych doświadczeniach, ale od razu muszę dodać, że były to także doświadczenia wielu moich starszych i młodszych ode mnie koleżanek i kolegów. Tak się złożyło, że spośród wszystkich zachodnich ośrodków naukowych jako pierwsze dla nas, szukających już własnej drogi polskich historyków sztuki mediewistów, szeroko otworzyło się Centre d'études supérieures de civilisation médiévale w Poitiers. To powstałe w roku 1953 przy tamtej- 
szym uniwersytecie centrum naukowe miało według jego twórcy Gastona Bergera - profesora filozofii, wyznawcy Husserla, dyrektora szkół wyższych we francuskim ministerstwie oświaty - mieć za przedmiot badań i nauczania na poziomie pomagisterskim szczytowy okres średniowiecza europejskiego: wieki dziesiąty, jedenasty i dwunasty. Zgodnie z koncepcją założyciela, każda $z$ trzech głównych uprawianych w tym ośrodku dyscyplin: historia, historia sztuki i historia literatury - ale także inne, choć mniej intensywnie obecne, jak historia filozofii, historia nauki i historia muzyki - miała utrzymywać swoją przedmiotową i metodologiczną tożsamość i odrębność. Zamysłem Gastona Bergera było wszakże to, by mogły się one w jednym miejscu spotykać. Pragnął on, by każdy ze studiujących w Poitiers młodych mediewistów mógł mieć wgląd w dziedziny badań inne niż jego własna. I by mógł stawiać pytania o związki rozpatrywanych przez siebie zjawisk czy dzieł z wydarzeniami, procesami społecznymi, ustrojem politycznym, duchowością, twórczością i warunkami życia epoki.

Dzisiaj taki postulat metodologiczny w naukach historycznych jest czymś zwyczajnym. We Francji lat 50. ubiegłego stulecia, ale nie tylko w tym kraju, program, który w pracy akademickiej nad jedną cywilizacją miał łączyć kilka dyscyplin, był nowością. O jego powodzeniu w Poitiers zdecydowało to, że Gaston Berger powierzył kierownictwo centrum dwóm doświadczonym profesorom miejscowego uniwersytetu - historykowi sztuki René Crozetowi, uczniowi Henriego Focillona, i historykowi Edmondowi René Labande'owi, a jednocześnie wyposażył założoną przez siebie instytucję w środki, które pozwalały zapraszać na wykłady i seminaria innych badaczy nie tylko z Francji, ale także spoza tego kraju. Jedynym warunkiem ich uczestnictwa była czynna znajomość francuskiego, ponieważ w tym języku były prowadzone wszystkie zajęcia. Wymóg ten spełniało, zresztą nadal spełnia, wielu uczonych spoza Francji i przez Poitiers przewinęli się wtedy, także nadal przewijają się, najwybitniejsi mediewiści z całego świata.

Nauczanie w Poitiers było wówczas prowadzone w dwóch cyklach: w ciągu roku akademickiego i podczas sesji letniej, która w pierwszych latach istnienia Centre trwała pięć tygodni. Sesja letnia była okresem szczególnie intensywnej pracy jej uczestników, ponieważ przedpołudnia zawsze wypełniały dwa wykłady dwóch profesorów reprezentujących dwie różne dziedziny mediewistyki, a popołudnia były przeznaczone na ćwiczenia przy zabytkach $\mathrm{w}$ tym bardzo bogatym w sztukę romańską i gotycką mieście. W soboty odbywały się wyjazdy na podobne zajęcia w najbliższych okolicach Poitiers i w sąsiednich dzielnicach, a ten obfity program ćwiczeń terenowych dopełniał trzydniowy objazd jednego z dalej położonych regionów Francji romańskiej. Nauczanie w ciągu roku akademickiego było mniej intensywne. Było ono dostosowane 
do potrzeb i rytmu pracy młodych mediewistów, którzy przyjeżdżali do Poitiers na roczny kurs zwykle $z$ własnymi projektami badawczymi. Nadal, wszakże, zajęcia prowadzili, obok miejscowych profesorów, uczeni z innych ośrodków naukowych, w tym zawsze liczni cudzoziemcy. Gdy studiowałem w Poitiers, wspomniany przed chwilą profesor René Crozet przygotowywał książkę o sztuce romańskiej w Saintonge. W swoich wykładach przedstawiał nam postępy w pracy nad tym tematem. Co dwa tygodnie zaś zabierał nas autokarem do tej dzielnicy, gdzie wraz z nim inwentaryzowaliśmy wybrane kościoły, on zaś na miejscu poddawał pod dyskusję swoje obserwacje, z niezwykłą szczodrością dopuszczając nas do udziału we własnych badaniach. Opisany tutaj program nauczania utrzymał się w Poitiers długo. Później uległ, niestety, częściowej redukcji. Nadal wszakże jego mocną stroną pozostaje to, że biorą w nim udział - jako nauczyciele i jako studenci - przedstawiciele różnych dziedzin mediewistyki z całego świata.

W latach 50. XX wieku i na początku następnego dziesięciolecia Centre d'études supérieures de civilisation médiévale stało się dla młodego polskiego mediewisty miejscem, w którym po raz pierwszy mógł on spotkać się ze światową historią sztuki bezpośrednio, nie tylko poprzez lektury. Mógł brać udział w wymianie poglądów, do czego dawały mu okazję przede wszystkim seminaria, ale także dyskusje z profesorami, które w Poitiers w czasie sesji letniej odbywały się po każdym wykładzie. A jednocześnie mógł ćwiczyć oko na największych osiągnięciach sztuki średniowiecznej, uczestnicząc w niezliczonych i obejmujących wielką część Francji wyjazdach terenowych. Mógł wreszcie rozwijać własne badania, korzystając $z$ archiwum fotograficznego, gromadzącego zdjęcia dzieł sztuki romańskiej z całej Europy, i z biblioteki, która wyróżniała się wielkim zbiorem czasopism. Niektórzy młodzi polscy badacze przybywali wówczas do Poitiers na studia całoroczne, inni przyjeżdżali tylko na sesję letnią, byli też tacy, którzy uczestniczyli w obu cyklach nauczania. Spośród bliskich mojemu pokoleniu - zarówno starszych ode mnie, jak i nieco młodszych - wymienię Zygmunta Świechowskiego, Lecha Kalinowskiego, Klementynę Żurowską, Stanisława Wilińskiego, Urszulę Popłonyk, Krystynę Józefowicz, Teresę Mroczko, Krystynę Białoskórską, Mariana Kutznera, Marię Otto i Andrzeja Tomaszewskiego.

Z jaką historią sztuki spotkał się młody polski mediewista, przyjeżdżając w tamtych latach na studia do Poitiers? We Francji, w której literatura o sztuce przeżywała od XVIII wieku wielki rozkwit, bardzo silnie był zakorzeniony pogląd na twórczość artystyczną jako zjawisko „autonomiczne” - dziedzinę działalności człowieka, której nie można opisać ani wyjaśnić inaczej, jak tylko w niej samej szukając źródeł jej tożsamości. Stanowisko to zaznaczyło się bardzo wyraźnie w sposobie badania architektury średnio- 
wiecznej, które zapoczątkował w latach 30. XIX wieku swoimi gruntownymi pracami Arcisse de Caumont. Wskazany przez niego kierunek naukowy, który miał wszystkie znamiona szkoły, rozwijało po nim kilka pokoleń uczonych. Zapisali się wśród nich na trwałe Auguste Choisy, Robert de Lasteyrie, Jean-Auguste Brutails, Camille Enlart, Eugène Lefèvre-Pontalis, Marcel Aubert, Paul Deschamps i Élie Lambert. Fundamentem ich badań była niezwykle staranna analiza struktury budowli. Towarzyszył jej rozbiór form architektonicznych występujących w poszczególnych jej częściach, połączony z dokładnym określeniem natury materiału użytego do konstrukcji i sposobu jego zastosowania. Celem była rekonstrukcja wewnętrznej chronologii budowy, tę zaś badacz skrupulatnie konfrontował z odnoszącymi się do rozpatrywanego dzieła źródłami pisanymi. Podkreślić trzeba, że badając pojedynczy kościół czy zamek, francuscy historycy architektury średniowiecznej szczególną uwagę poświęcali przekazom, które przynosiły informacje o prowadzonych przy zabytku późniejszych robotach budowlanych. Ich monografie cechowało staranie o dokładne odróżnienie w dziele tego, co pochodziło $z$ czasu jego powstania, od tego, co wniosły doń późniejsze wieki. A do krytyki źródła byli wspaniale przygotowani. Sześciu z wymienionych tutaj kontynuatorów hrabiego de Caumont było absolwentami znakomitej École nationale des chartes, jeden z nich ukończył nie mniej świetną École normale supérieure, a tylko jeden z nich, Auguste Choisy - polytechnicien. Szybko rosnąca wiedza o pojedynczych budowlach rychło kazała tym badaczom postawić pytanie o miejsce każdej z nich w dziejach architektury pojmowanej teraz przez humanistykę jako historia osobnego gatunku artystycznego. Z prowadzonych intensywnie porównań rzutów poziomych i rzutów elewacji, rozwiązań konstrukcyinych, detali i sposobów obróbki budulca w poszczególnych dziełach zaczął stopniowo wyłaniać się obraz grup typologicznych i stylowych, obraz zresztą podlegający ciągłej ewolucji wskutek stale zmieniających się i często spornych kryteriów klasyfikacji.

Powie niejeden czytelnik, że wszystko, co przed chwilą opisałem, to nic innego, jak wdrażanie podstawowych wymogów metodologicznych historii sztuki i elementarz pracy nad architekturą. Na pewno tak. Ale nie wspominałbym tutaj francuskich badań nad architekturą średniowieczną, gdyby nie to, że badania te były, zresztą nadal są, nacechowane największą precyzją rozbioru formy, a dokładność analizy oddaje język. Francuska historia sztuki wypracowała terminologię, która starannie przekłada na pojęcia nawet najbardziej złożoną strukturę dzieła i jej elementy składowe w całym bogactwie ich zróżnicowania. Zapis tego języka przynoszą wzorowe słowniki terminologiczne wydawane przez Éditions du patrimoine, wśród nich - w zakresie architektury - arcydzieło gatunku napisane przez Jean-Marie Pérouse de Montclos, 
Architecture: description et vocabulaire méthodiques (Paryż 1972, nowe wydanie: 2011).

Trzeba podkreślić, że ta francuska szkoła badań nad architekturą średniowieczną zajęła wśród prądów humanistyki swojego kraju osobne pod względem metodologicznym, samodzielne miejsce. Wyrażała jej odrębność nawet nazwa, która jej w języku akademickim od początku towarzyszyła: archéologie française du moyen âge. Uczeni, którzy tę szkołę tworzyli, skupieni byli w założonej jeszcze przez hrabiego de Caumont w roku 1834 Société française d'archéologie. Wydawała ona - i nadal wydaje - dwa stojące na bardzo wysokim poziomie tytuły: serię „Congrès archéologique de France” (od 1834) i kwartalnik „Bulletin monumental” (od 1835). Dodajmy jeszcze, że $z$ tego środowiska naukowego wywodził się personel Service des monuments historiques, urzędu konserwatorskiego również w tym samym czasie przez hrabiego de Caumont założonego. Nie mamy tutaj miejsca na to, by wchodzić w przyczyny, dla których Arcisse de Caumont przyjął nazwę „ archeologia” dla badań nad architekturą średniowieczną. Wystarczy zauważyć, że termin ten we Francji wyraźnie odgraniczał pole pracy zajmujących się nią uczonych od zakresu badań nad innymi dziedzinami i okresami w dziejach sztuki. Ta odrębność środowiska historyków architektury średniowiecznej utrzymuje się zresztą we Francji w dużym stopniu do dzisiaj.

Kiedy w roku 1957, podczas któregoś z objazdów terenowych odbywających się w ramach sesji letniej Centre w Poitiers, stawaliśmy przed romańskim albo gotyckim kościołem i słuchaliśmy, jak go przedstawia Marcel Aubert, wielki autorytet w ówczesnym świecie badań nad architekturą Francji średniowiecznej, autor kilku monografii jej najważniejszych przykładów i ojciec nowoczesnych studiów nad kościołami i klasztorami cystersów, jego drobiazgowa analiza budowli wypowiadana klarownym językiem odsłaniała nam dzieło w całym bogactwie jego rozmaitych form. Kiedy kilka miesięcy później uczestniczyliśmy we wspomnianych już całorocznych zajęciach profesora René Crozeta na terenie Saintonge, mogliśmy teraz sami, prowadzeni przez naszego wykładowcę, próbować rozbioru form tamtejszych kościołów. Uczyliśmy się wnikać w dzieło, rozpoznając jego części składowe i ich porządek, a stworzona przez francuską naukę szczegółowa terminologia architektury budowała w naszej pamięci intelektualny gmach pojęciowych odpowiedników zarówno struktury budowli, jak i jej elementów. Te składniki bowiem dają się wyodrębnić, nazwać i policzyć. Można w liczbach określić ich wielkość, można opisać ich miejsce w strukturze dzieła i w liczbach zmierzyć występujące między nimi odległości, więc ująć w słowach zachodzące między nimi relacje. Żródła pisane dotyczące dziejów tych kościołów dopiero wtedy były rozpatrywane, kiedy oko już rozpo- 
znało w budowli jej artystyczną tożsamość i wewnętrzną historię, a umysł pozwolił to wzrokowe poznanie przełożyć na słowo. Dla mnie, wychowanka poznańskiej historii sztuki, były to lekcje, które niezmiernie wzbogacały wyniesioną z macierzystego uniwersytetu znajomość instrumentów analizy formalnej. Jednocześnie umacniały przekonanie - również na studiach w Poznaniu ukształtowane - że prawidłowa analiza formy dzieła stanowi bezwzględny warunek powodzenia wszystkich operacji poznawczych w naszej dyscyplinie.

Czytelnik mojego artykułu może postawić pytanie, dlaczego historyk sztuki, który nie zajmuje się architekturą, kiedy mówi o swych latach nauki, tak mocno przywołuje na pamięć francuskie badania akurat nad tą dziedziną. Może też zasadnie pytać, dlaczego wyróżniłem kierunek metodologiczny, który był i pozostaje studium formy, a intelektualne uznanie, jakie on we mnie wzbudził, dokonało się w czasie, kiedy historia sztuki - wtedy już w skali światowej i we wszystkich swoich zakresach - energicznie szukała wyjścia poza horyzont badań nad formą; kiedy zaczęła szukać w dziele sztuki świata idei. Tego przełomu byliśmy wtedy świadomi. Wielu z nas, wyjeżdżając na studia do Francji, było już po lekturze Studies in Iconology Erwina Panofsky'ego albo przynajmniej znaliśmy główny postulat metodologiczny jej autora, który kazał na końcu drogi poznawczej pytać o to, jak w badanym dziele sztuki przejawia się współczesna mu kultura. Ja sam pozostawałem w tamtym czasie pod urokiem wielkiej wizji Ottona von Simson, który zalaną kolorami witraży gotycką katedrę wywodził z metafizyki światła, karmiącej się pismami czczonego w Saint-Denis Pseudo-Dionizego, oraz z neoplatonizmu szkoły katedralnej w Chartres - środowiska uczonych dopatrujących się obrazu harmonii wszechświata w jego matematycznych prawach. Sam też już wówczas próbowałem odnajdywać w badanym przez siebie dziele - choć na pewno czyniłem to bez należytej staranności i ostrożności - przesłanie ideowe, które przyszło do warsztatu artysty z zewnątrz, wraz z zamówieniem i które miało być dla patrzącego na to dzieło człowieka epoki czytelne. Dodajmy, że ówczesnej nauce francuskiej, tak przywiązanej do pojmowania twórczości artystycznej jako zjawiska autonomicznego, nie było obce rozpatrywanie sztuki jako przekaźnika idei. Kraj ten wydał w XIX wieku dwóch wielkich mediewistów, którzy położyli fundamenty pod badania nad wpływem średniowiecznej teologii, egzegezy i liturgii na ówczesną twórczość artystyczną. Byli to jezuici Charles Cahier i Arthur Martin. W tym samym kierunku, ale jeszcze dalej, poszedł Émile Mâle. Dopatrując się bezpośredniej zależności najwybitniejszych dzieł rzeźby, malarstwa i rzemiosł artystycznych francuskiego średniowiecza od ściśle określonych myśli nauczania chrześcijańskiego, stworzył monumentalny obraz sztuki 
tej epoki jako narzędzia pastoralnej misji Kościoła. Nie ma tutaj miejsca na porównywanie dorobku i metody tego uczonego $z$ tym, co postulował i co ukazywał w swoich pracach Erwin Panofsky; zainteresowanych tą kwestią odsyłam do tego, co na ten temat napisał Pierre Francastel w swej książce Études de sociologie de l'art (1970). Nie mogę jednak, poruszając ten temat, nie zauważyć, że mimo różnic w ich podejściu do przedmiotu badań można też dostrzec $\mathrm{w}$ ich sposobach interpretacji sztuki podobieństwa. Oddziaływanie Émile'a Mâle'a na współczesną mu i powojenną historię sztuki nie było tak szerokie jak porównywalny w tym zakresie tematycznym wpływ Panofsky'ego. Niemniej jednak uczony francuski miał swoich kontynuatorów i kiedy studiowałem w Poitiers, zetknąłem się z nimi. Wymienię spośród nich jednego - wielkiego mediewistę Ludwika Grodeckiego, ucznia Henriego Focillona, ale jednocześnie badacza związanego z Service des monuments historiques i - poprzez to środowisko - dobrze znającego tradycję francuskich badań nad architekturą średniowieczną. Jego wykłady o witrażach francuskich XII i XIII wieku, których słuchałem w Centre d'études médiévales w roku 1957, budziły najwyższy podziw głębią spojrzenia na te pełne przedstawień barwne segmenty ścian kościoła średniowiecznego. Grodecki, badając je, ukazywał, jak bardzo kompozycje i formy figuralne zastosowane w poszczególnych kwaterach witraży współgrają z treścią przekazu doktrynalnego wyobrażeń - często przekazu o wyrafinowanej treści teologicznej. Autor wyraźnie podkreślał inspirację, jaką było dla niego wielkie dzieło Émile'a Mâle'a, a w drukowanych wersjach jego prac przypisy to potwierdzają. Był także pod wpływem Panofsky’ego, z którym złączyła go przyjaźń intelektualna, gdy na zaproszenie tego uczonego przebywał w latach 1949-1950 w Institute for Advanced Study w Princeton. Mówiąc o obecności we Francji tej historii sztuki, która dopatrywała się bezpośredniego wpływu świata idei na twórczość artystyczną, nie można wreszcie pominąć tego giganta naszej dyscypliny jakim był André Grabar, uczeń Nikodema Kondakowa i Dymitra Ajnałowa. André Grabar zrewolucjonizował - nie waham się użyć tego słowa - studia nad sztuką wczesnego chrześcijaństwa, Bizancjum i krajów chrześcijańskiego Wschodu dwiema swoimi już we Francji ogłoszonymi pracami: L'empereur dans l'art byzantin. Recherches sur l'art officiel de l'empire d'Orient (1936) i Martyrium. Recherches sur le culte des reliques et l'art chrétien antique (1946). Wszechstronność jego spojrzenia na czynniki ideowe i społeczne, jakie wywarły wpływ na działalność wielkich ośrodków artystycznych greckiego Wschodu, oddziałała ożywczo także na studia nad sztuką Zachodu. Jego pionierskie dzieło o przedstawieniach cesarza wschodnio-rzymskiego z roku 1936 było wielkim źródłem inspiracji dla autorów szybko narastających po wojnie prac nad ikonografią polityczną 
w krajach kultury łacińskiej. Słuchałem wykładów André Grabara o sztuce bizantyńskiej w Collège de France i miałem też przywilej kilkakrotnie spotkać go osobiście oraz z nim dłużej rozmawiać. Sposób, w jaki mówił i pisał o odbiciu duchowości świata greckiego w późnoantycznej i średniowiecznej sztuce cesarstwa wschodniego, był porywający.

Powtórzę więc tutaj, że gdy studiowałem we Francji, ten wielki nurt badawczy, który szuka w sztuce świadectw idei - nurt zresztą metodologicznie i przedmiotowo zawsze bardzo zróżnicowany - był już trwale obecny w świadomości mojego pokolenia. Z chwilą jednak, kiedy stawałem wówczas przed romańskim czy gotyckim kościołem i zagłębiałem się w jego architekturę - pytania, które nurt ten stawiał, nagle znikały z mojego pola uwagi. Pochłaniało mnie wtedy co innego. Prowadzony przez mojego profesora, odkrywałem budowlę jako osobne, zamknięte w sobie uniwersum form, równocześnie także jako zbiór elementów, które jeden porządek wewnętrzny spaja w organiczną całość. Mój przewodnik, zbrojny w rozbudowaną, szczegółową terminologię, z precyzją wyróżniał i nazywał każdą część dzieła, od najmniejszej do największej, i równie dokładnie opisywał zachodzące między nimi relacje. Jego lekcja ćwiczyła wzrok w rozbiorze formy i jednocześnie uczyła przekładu na słowa tego, co wzrok w oglądanym przedmiocie wyodrębnia. Jeżeli mogę tu użyć metafory, była to historia sztuki, która do dzieła „przylegała”. Wiedziałem oczywiście i wiem dobrze, że nauka, jaka płynęła $z$ godzin spędzonych $z$ moimi francuskimi nauczycielami przy średniowiecznych kościołach, była przedmiotowo ograniczona. Metod pracy nad architekturą nie da się zastosować do badań nad sztukami przedstawiającymi. Ale godziny te, jak żadne inne, uczyły młodego historyka sztuki staranności w analizie dzieła i odpowiedzialności za słowo, które o twórczości artystycznej wypowiadamy. A tej nauki nie można przecenić. Znamy nasze zmagania z językiem, kiedy mówimy czy piszemy o sztuce. I to na każdym poziomie procesu poznania: $\mathrm{w}$ opisie, $\mathrm{w}$ analizie, $\mathrm{w}$ interpretacji. Tymczasem studiując średniowieczne kościoły we Francji, stąpaliśmy na mocnym gruncie analizy morfologicznej wypracowanej w długoletniej praktyce badań - przy tym analizy artykułowanej precyzyjną terminologią. Było to intelektualne wyzwanie. Zapraszało do starania o podobny rygor w pracy nad innymi dziedzinami sztuki. Ale było w tych lekcjach jeszcze coś innego, co było dla mnie nie mniej znaczące. Prowadzone kolejno przy różnych kościołach analizy, właśnie dzięlki ich sumienności, uczyły postrzegać każde $z$ tych dzieł jako twór artystyczny jednorazowy, niepowtarzalny. A rozpoznanie odrębności pojedynczego dzieła sztuki jest kluczem do pojmowania sztuki w ogóle i probierzem naszej pracy. Ale to już jest inne zagadnienie i na tej obserwacji wypada mi zamknąć te wspomnienia. 
Piotr Skubiszewski

Professor emeritus, University of Warsaw

FACING THE WORK OF ART.

MEMORIES OF MY STUDENT YEARS

\section{Summary}

The present essay includes the author's memories of his university studies and the intellectual formation that he received as a student of art history at the University of Poznań in 1949-1954. His first professor who opened to him the door to art history and exerted on him a strong intellectual influence, was Szczęsny Dettloff, a disciple of Heinrich Wölfflin in Munich and Max Dvořák in Vienna. Dettloff taught his students that the foundation of studying art in history is the study of the form of an individual artwork He believed that without a proper analysis of form it is impossible to construct appropriate series of the works of art and specify their position in the culture of the times of their origin. Similar sensitivity to form and the understanding of its significance for the art historian's work were represented by two other professors important for the author, both educated by Dettloff already before World War II: Gwido Chmarzyński and Zdzisław Kępiński. When in 1957-1968 the author was a postgraduate student in the Centre d'Études Supérieures de Civilisation Médiévale at the University of Poitiers (CÉSCM), it turned out that the local methodological tradition was similar to what he had learned in Poznań before. The CÉSCM was founded as a multidisciplinary institute for the study of the Middle Ages, combining history, art history, literary history, and the history of ideas. It was important that one of them could shed light on an object studied by another, but each of them, including art history, kept its material and methodological identity. In the French tradition, art history had an "autonomous" status, focusing on artistic creation as a special sphere of human activity. That idea influenced also quite strongly the study of medieval architecture, originated in the early $19^{\text {th }}$ century by Arcisse de Caumont, and continued until today by many generations of French scholars. What is characteristic of their research is meticulous analysis of form, articulated with a precise, detailed, and comprehensive specialist vocabulary. The lectures of French scholars on medieval architecture, which the author attended in Paris and Poitiers, taught him precision in the analysis of the artwork's structure and its components, as well as responsibility for every single statement made on art. For a young art historian who did not specialize in architecture but in representational arts, that French experience was a lesson of methodological rigor necessary in the intellectual pursuits of the humanities scholar.

Keywords:

University of Poznań - art history, University of Poitiers - art history, methodology of art history, art history around 1950 